\title{
Chapter 21 \\ An Echo from a Footprint: A Step Too Far
}

\author{
Steve Webb
}

\begin{abstract}
Rarely in archaeology do we see the flesh and blood of ancient people living their lives? In Australia, a unique archaeological site discovered in 2006 allowed us to do just that as people went about their daily lives during the last glacial maximum. The site is a palaeofilm of men, women and children, walking, running and meandering across a wet area that was obviously special to them. While hundreds of footprints displayed this unusual but moving life tapestry, details of their behaviour and other marks they left behind were difficult or impossible to interpret. Moreover, were some of the marks made by humans or just artefacts of nature? Perhaps we were not making the right interpretation and not picking up clues to the everyday life of these people as well as we might. We required interpretative skills we did not have. To help us we needed to partner with people who had such skills. Pintubi people from Central Australia were asked to help, and they were some of the last people contacted by White Australia in the early 1960s. They had the vital skills of tracking, skills that had kept them alive in the harsh Tanami and Gibson deserts of Central Australia. It was possible that they would be able to apply those skills in reaching out to their ancient Dreamtime ancestors. They also brought that Dreamtime to us.
\end{abstract}

Keywords Ancient Australians · Pintubi · Tracking · Ice Age

\section{A New Footprint}

The current geological epoch is the Anthropocene. It is so named because of the significant impact we have made on the planet's climate and environment. It's not a good impact, and it's nothing to be proud of, but we are arrogant enough to put up a banner naming this infamous epoch after us. Anthropocene really means a time

\footnotetext{
S. Webb $(\square)$

Bond University, Gold Coast, Australia

e-mail: stwebb@bond.edu.au 
when humans have made a measurable impact on the planet, although no one agrees on exactly when it started.

The human population has grown almost to the point where we need two planets to support us. We have over 7.5 billion now and will have 9.7 billion in 2050 and 11.2 billion by 2100 . Such growth has already taken us through an equanimity with our environment and the other life forms with which we share the earth. We have moved into a time when our footprint has brought about a significant extinction event for its animals, so much so that it is ranked with the top six of the past nine major extinction events which the planet has undergone in its 4.5 billion-year history. We have eliminated earth's natural forests and poisoned its oceans, and humans are beginning to undergo a slow strangulation of themselves through that process and collective greed. That is a footprint!

We can see the effects of that footprint all around us via the many trackways we leave behind. They are presented to us incessantly by the media, social and otherwise, as well as our own eyes. One trackway is our ever-expanding cities, roads and other forms of built environments we are putting in place of the natural environment. Another is our warming world. Except for the oceans, there is little left of the world that hasn't been visited, influenced or damaged by our presence, actions and the overwhelming technological and mechanical know-how that enables us to exploit it. Once, we were as close to animals as family. We painted them, we carved them, we needed them, we worshipped them, and we revered them, so we might survive because we so depended upon them. We also killed only those we needed for food and skins. People are just now beginning to wake up to the fact we are a menace not only to the welfare of the planet but to ourselves. That is a footprint!

Why do we do it? Perhaps because we have become removed from nature and, in reality, far removed from our ancestors, almost as though we are unrelated strangers. We are now the hominin that will kill off the planet's animals for profit, rip out their environments, pollute the oceans with plastic and other modern dross, destroy ecosystems to graze one or two domestic livestock species and plant monocultures like palm oil and soy beans replacing natural ecosystems and the animal species that relied on and evolved in them. Some of the last indigenous people, like those of the Amazon, Australia the Arctic and Southeast Asia, know those things and try to stop the destruction, at present in vein. In the oceans we destroy the marine equivalent of rainforests, coral reefs, with dynamite to catch a few fish, with overfishing in waters of local peoples to feed billions elsewhere. And we have human-induced rising water temperatures changing oceanic ecosystems, changing fish habits and destroying trophic systems.

We are no longer the pioneering people who strode the earth, inhabiting all the continents in the Pleistocene. Perhaps we became too strong, and we produced too many of us for our own good, so that we could no longer see the consequences of our activities and because we have lost our affinities with our natural world. We are killing planetary life through anthropogenic climate change and consciously by stealth. We poach, kill and traffic horn, body parts and living creatures. We do it for greed and profit and to fund wars. Other reasons include the need for quack potions, false aphrodisiacs, meaningless medicines, artless carvings and pointless 
ornaments and to supply foreign currency for corruption and drug trafficking by all nationalities and creeds.

Animals belong to all of us as our natural heritage, and they are supposed to be in our care. They are under severe pressure, but we kill them for sport: one more death won't make any difference! We humans have become greedy and thoughtless about our fellow animal travellers and the earth on which we stand. Many of us are bereft of common decency, humility, humanity and the ethical and moral considerations that made us different from animals and arose from the Enlightenment.

Our archaeological footprint will be easily seen for all who visit this planet in future. It will not take painstaking work to piece together our lifestyle and legacy like it does for an archaeologist today to reconstruct the past. Unlike people in the Pleistocene, we have become separated from the earth. Most of us live in cities, suspicious of and cringing away from open spaces and fearing the wide outdoors like skulking cowards. Cities are places where it is easy to think we no longer need the earth and be close to it or need to know anything about its workings and interrelationships. Most humans are totally ignorant of how it works, nor do they care because food appears in the supermarket and when they have had enough to eat, they throw it away, unlike the old hunter-gatherer that would save surplus in case the hunting and gathering doesn't work for a few days or even weeks. That huntergatherer also knew all about the interconnectedness of earth's systems and being part of the rich tapestry of life that surrounded them. It was not by scientific knowledge but by watching and gathering experience during their lifetimes. It was also passing that knowledge on to the next generation. If they didn't have that knowledge and understanding, they died. They lived close to the environment, but like them our future depends on the world around us and how we treat it. Our forefathers wandered through a world that they knew and totally relied on. They survived not only because of what they knew but what they could learn, knowing every tree in their forest and rock on their hillside. Through scientific endeavour we now know more than they did about the intricacies of the earth, so you might think we should know better. But we don't; unlike them our knowledge seems to have had quite the opposite effect and moved us farther from it.

Today, we have swapped the rocky cave for an electronic cave that separates us from the real world and teaches us all we need to know from the comfort of an armchair or desk. Unlike our ancestors we do not leave our cave very much and explore what is around us. But we hope the electronic pathway we tread and computer screen we gaze at incessantly will take us where we want to go. We don't really have to go and see or experience the world for ourselves. We don't have to touch it, smell it, listen to it, taste it or feel its temperature like our ancestors had to do to survive. We hope our earth will naturally save us and continue to provide for all our wants and needs and save us from ourselves: that is if people think about the earth at all but it is clear many do not. 


\section{An Old Footprint}

What if we could step back two epochs, skipping the Holocene, to the Pleistocene, when most of the footprints discussed in this volume were made? What if we looked for a different footprint than that discussed above? What if we looked around for evidence of humans? Unlike today, it is more than likely we could not readily find it and that would be so even in the Late Pleistocene. If we were very lucky, we might stumble upon an open camp site and find some smashed stone or flakes or even the odd patch of burnt ground or old hearth. We might even find a scarred tree or the meagre remains of an old kill or a broken, discarded implement, perhaps some broken branches if we were very lucky. But any of these things would be few and far between. From the highest viewpoint, we would not see a human presence unless it was a wisp of smoke far in the distance perhaps wafting up from a dense and seemingly endless blanket of forest. We would, however, see quite a lot of different animal species, insects and plenty of clean drinking water. We might even see animal tracks and if we were very lucky the human tracks following the animal, if the weather did not eliminate them first. Tracking was a vital and necessary skill of the people then. Knowing what animal made the track, which way it was going and when it had made the tracks was the real skill of the tracker and the key to survival. That skill is fading away, but it can still be found if one looks hard enough.

A very rare event took place in Australia in 2003. It was during a small survey being carried out by Aboriginal people and myself in the Willandra Lakes World Heritage Area in western New South Wales (Fig. 21.1) that we found footprints. It was almost something akin to the scene just presented above. It was a remote area, and there was no sign of humans or their works except the people I was with. There was no sign of modern humans on the ground either, just a few stone flakes and some freshwater mussel shell left over from a Late Pleistocene gathering expedition. We were walking across a blowout where sand had been removed from a harder indurated surface below. To our right was a large sand dune that we were approaching with someone in front of me. There, in front of the young Aboriginal lady was a human footprint on a unique light grey clay surface, exposed by the retreating sand dune. I was several metres away following behind her when she turned and asked me: "Is this a footprint?"

The Willandra Lakes Region encompasses a series of fossil freshwater lakes that finally dried out around 15-12 ka. The criteria for the Willandra's World Heritage listing required the area to possess outstanding universal cultural and/or natural heritage values. The Willandra certainly does, so that criteria was satisfied, and World Heritage status was conferred in 1981. The region has been occupied by humans who camped on the lakeside beaches from at least $45 \mathrm{ka}$. Very special discoveries of both cremated and non-cremated human remains have been made there. From those it has been possible to reconstruct the cultural, ceremonial and belief systems practiced by some of Australia's oldest residents as well as their artefactual capabilities and use. 


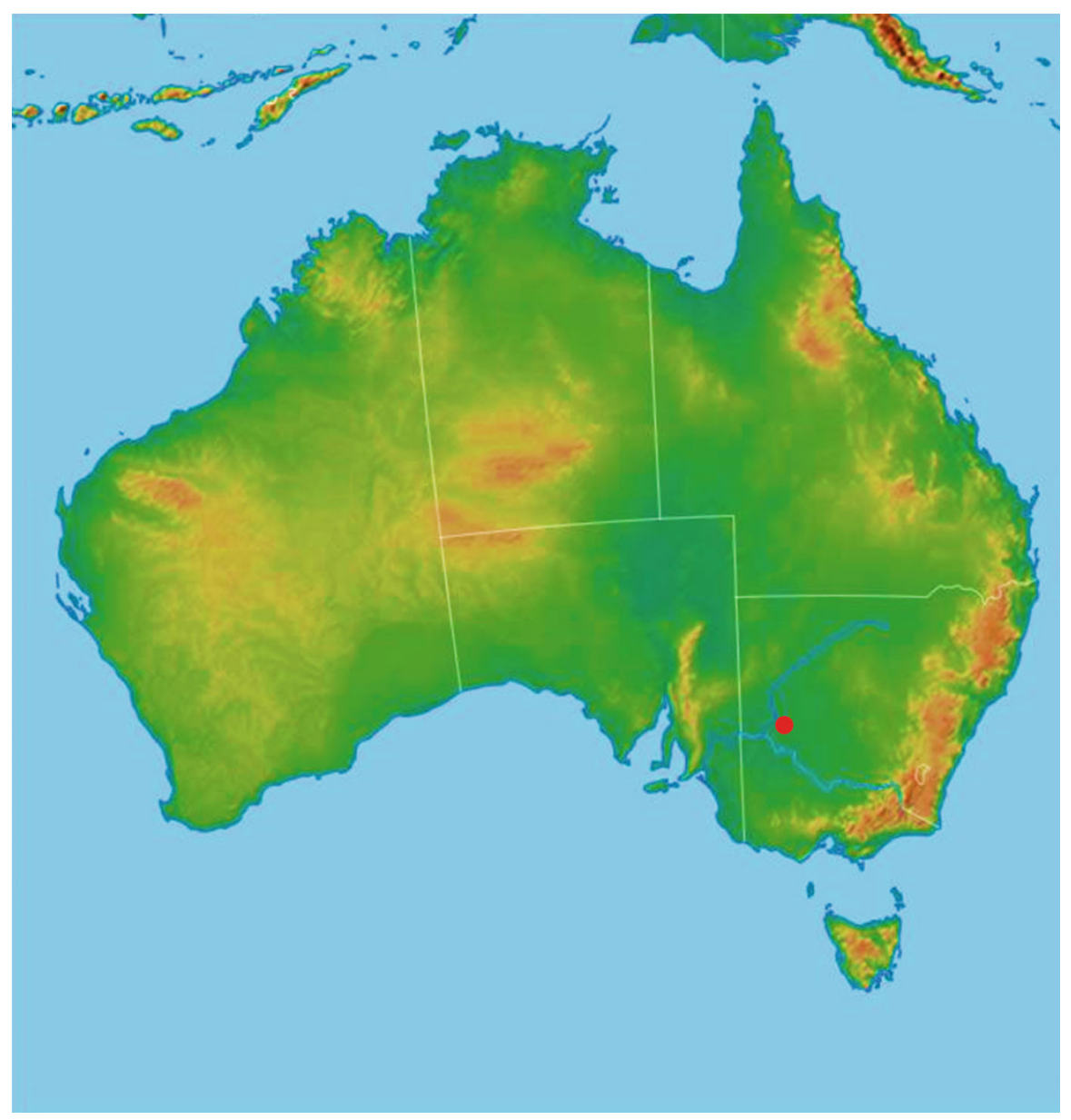

Fig. 21.1 Willandra Lakes World Heritage Area in western New South Wales

The fossil footprint discovery work operated over 2 years revealing hundreds of footprints, dated to between 25 and $20 \mathrm{ka}$ (Webb et al. 2006; Webb 2007). They were found on a rare $850 \mathrm{~m}^{2}$ magnesite clay pavement, a sediment not previously found in the region (Fig. 21.2). The discovery eventually uncovered over 700 prints, some forming 23 trackways (those composed of four or more consecutive footprints). The longest consisted of 29 prints. The site presented an area of activity by both adults and children moving in various directions with some intriguingly walking side by side, some meandering across the site and others walking over previous prints (Fig. 21.3). The site obviously indicated a group of Ice Age people going about their daily lives but seemingly concentrating on this particular spot in a rather purposeful manner, probably indicating this place was a special natural or perhaps ceremonial site of some kind. There was something else that was fascinating about 


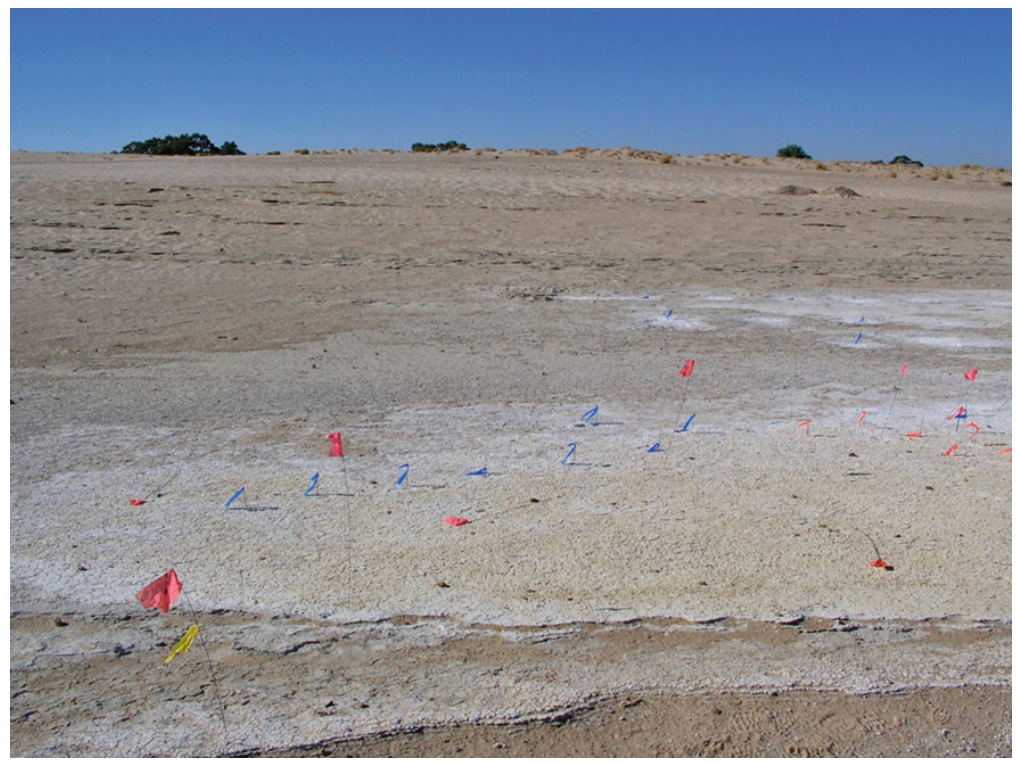

Fig. 21.2 The grey magnesite surface where the prints were found with the retreating sand dune in the background

Fig. 21.3 Uncovering a trackway by predicting its direction and using the stride length to place where the next footprint should be

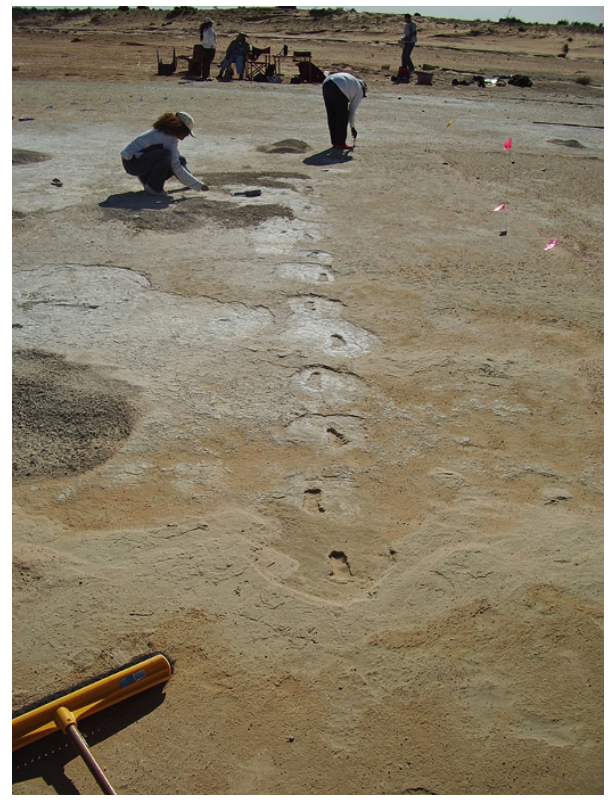


Fig. 21.4 The site composed of several layers indicating cyclical filling of the pond. All layers had prints and marks on them

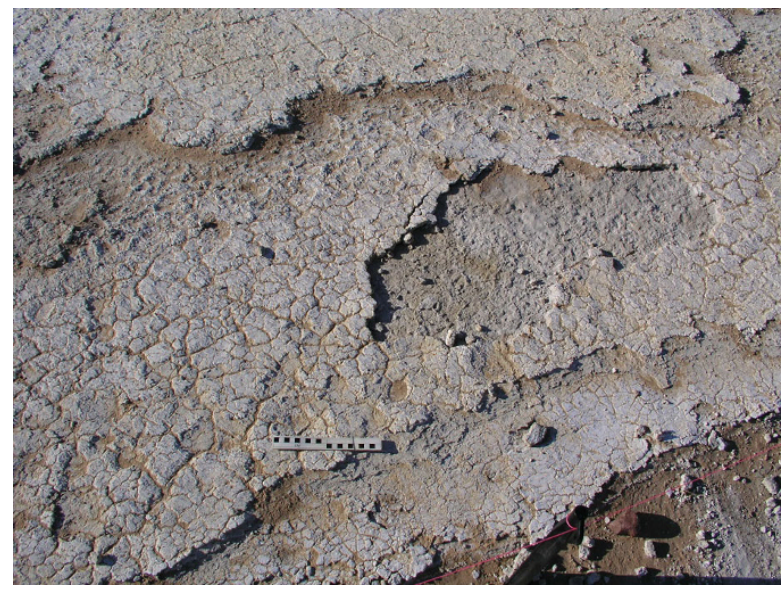

the site; it consisted of at least six layers on top of one another (Fig. 21.4). All these had footprints or other marks on them consistent with activity.

Some male prints formed long meandering tracks, while four told of a group of men running fast and parallel to each other while making a slow curve to the right, as they might while hunting game. What was clear was that the footprints represented a unique social gathering of some kind with men as tall as $1.94 \mathrm{~m}$ and one running at up to $37 \mathrm{~km} / \mathrm{h}$. More importantly, the prints brought the people to life in a way no other archaeological evidence could. Creases beneath the feet of some prints brought that special feeling of seeing flesh, life, tissue and blood. These people were acting out their daily activity at a time when the world was deep in an Ice Age. Someone could walk south from Australia to Tasmania or north to Papua New Guinea by land bridges exposed during low sea levels. An even longer walk was possible from Dublin to Tierra del Fuego without getting your feet wet.

The prints showed life, the life and the actions of people long disappeared. They must have been gathering around a shallow but moderately large pool of water possibly formed when the nearby lake was full and sent groundwater seeping underground across to this place. The resulting vegetation growing in and around the water may have made it an ideal place, attracting birds and animals and an obvious target for hunter-gatherers. These tracks now exposed the activities of such a group or band whether in multiple events of a few people or only one or two of many people. Perhaps it was a transient community that normally lived far away, or was it a local band that focussed on the Willandra Lake system? Whatever the case, the prints made a very real and unique human connection across millennia with those of us who viewed them through the intimate shape and features of their feet. The tracks of three children meandering across one another showed, for example, the typical behaviour of children (Figs. 21.5 and 21.6). Together, wandering about but going in the same general direction as children do: these children of the Ice Age spoke to any father or mother of today. 
Fig. 21.5 An adult and several children's tracks move across the surface and off site, disappearing under a large sand dune behind the site. Local Aboriginal Elders look on. The track of the one-legged man crosses below in strides of over 2 metres. (Photo M. Amendolia)

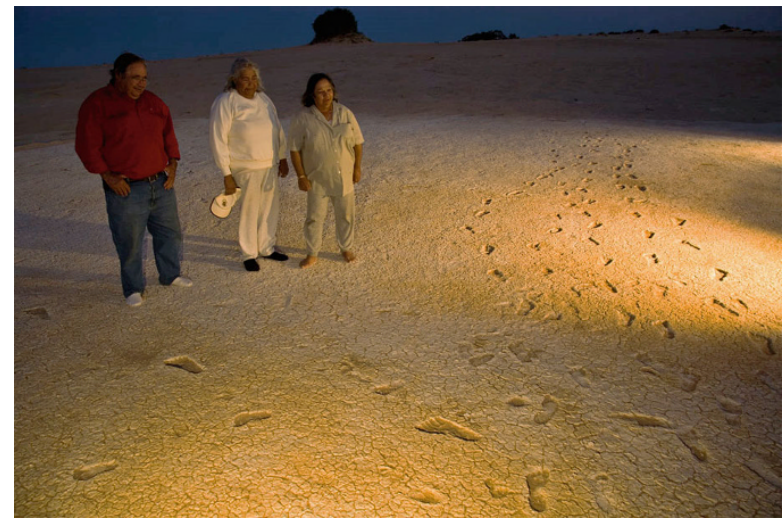

Fig. 21.6 A lone child of 20,000 year ago makes its way across the site at sunrise. (Photo M. Amendolia)

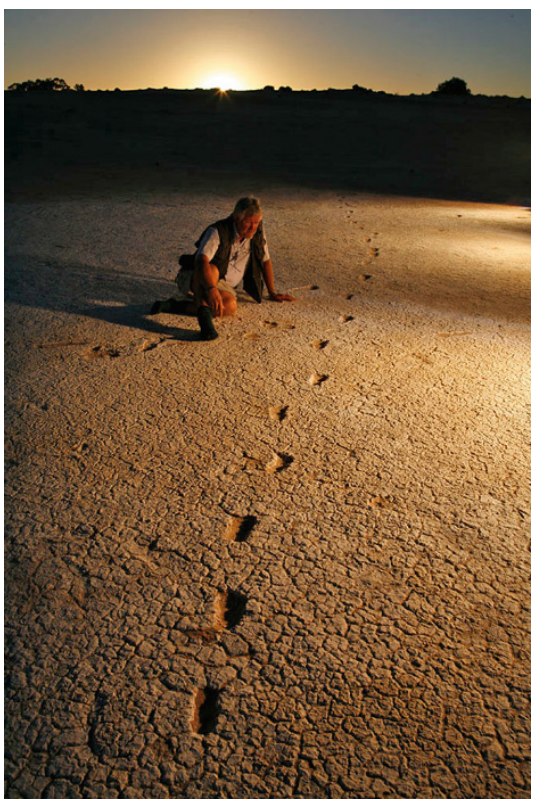

Our interpretations of this special evidence, unique in Australia, were not enough, however. There was the strong feeling that while we could make good educated guesses about the site and offer suitable answers of what it might be about, the unique marks and prints on it needed a deeper interpretation, if possible. This was evidence from the past that was above and beyond the normal archaeological approach. This site was, to all who saw it, something that we had to wring the last piece of information from if possible. We worked for weeks looking at the marks and the prints. We could take various measurements, but it was as though they were enigmatically hiding information that would make them really come alive. It was then I began to think about who could help with interpreting the site. There seemed 


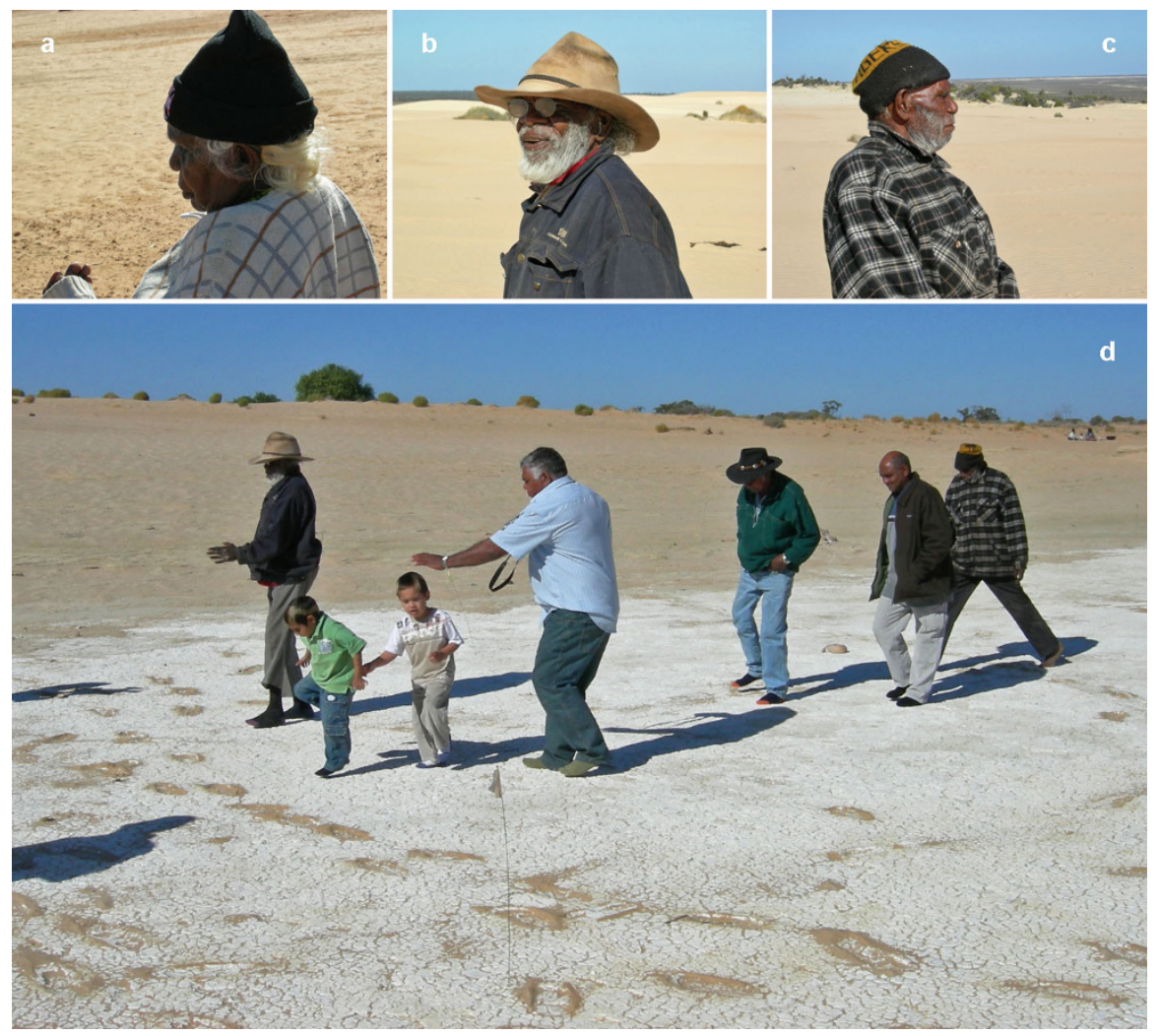

Fig. 21.7 (a) Mijili Napananga; (b) Paddy Japananga; (c) Johnny Napurula; (d) Paddy Japananga leading the way with members of the local community and Johnny Napurula bringing up the rear while pacing out a track

to be no one, certainly not in the archaeological field that had any experience with such a task. What we needed was someone who knew about footprints and tracking. It seems trite, but what we needed was those who could track!

It seemed logical to turn to any Aboriginal people that could track. While many might be able to do that or claim to be able to, some would be better than others. I contacted a non-Aboriginal friend in Central Australia to ask him about contacting such people there. But is was not just contacting them, would they be willing to come down to the Willandra $2000 \mathrm{~km}$ away, and how could we arrange that even if they would? My friend put me in contact with another non-Aboriginal person who knew trackers. That person was Peter Bartlett Japaljari who was married to Cindy Nakamarra, a Pintubi woman. He had spent many years in Central Australia, knew many Pintubi, Warlpiri, Pitjantjatjara and other tribal people from across the region. Importantly, he had been initiated and knew several of the desert languages. Cindy's mother Mijili Napananga was a brilliant and very famous artist and a Pintubi Elder (Fig. 21.7a). Her group had been contacted in the early 1960s by the anthropologist 
Donald Thomson (1975). He had mounted two expeditions to look for some of the last desert people living totally isolated in Australia's centre without ever contacting non-Aboriginal people. People were known to be living out in some of the remotest desert regions because as small track building gangs had pushed through some areas, they had encountered a few of the people. Mijili and her group had been living much as their ancestors had been doing for thousands of years. So, when Thomson arrived, it was the first time she and her group saw non-Aboriginal people.

In the late 1950's and early 60's Australia was involved in testing the Blue Streak and other missiles and even the detonation of Atomic devices on behalf of Britain that was the reason for basic tracks being built prior to the launches. Some effort was now being made to contact the desert dwellers who were still living in the remotest parts of Central Australia so they could be removed from the path of missiles. Similar expeditions had contacted Mardu people in the western Gibson Desert in northwest Australia, and they had been removed from missile trajectory paths although, later, it was found a few had remained out there.

Thomson visited the camps of the Pintubi and took many pictures of them and their lifestyle (Thomson 1975). Whether true or not, the Pintubi name is synonymous with living in the harshest of Australian environments. But perhaps an even more truism is that they are known as survivors and the last of them came in as late as 1984. Thomson's record depicts a very harsh landscape that makes one wonder how anybody could have gathered enough food to survive. People were thin, almost completely without body fat, but nevertheless reasonably healthy. In contrast the children were chubby and happy and enjoyed playing at hunting small lizards with toy spears and collecting them in their hair string belts tied around their waists. The key to finding the meagre menu on offer in the eastern Gibson and western Tanami Deserts was being able to make the most of the creatures that lived out there. Unfortunately, the protein mainstay of the diet was only a few small lizards, such as thorny devils (Moloch horridus), snakes and witchetty grubs. So the skills of tracking had to be at their best with such small game to follow and tracks that could disappear with a puff of wind.

Besides Mijili and her daughter, Peter Bartlett Japaljari was also able to contact two male Pintubi Elders Paddy Japananga and Johnny Jupurulla who also had had no connection with non-Aboriginal people till their early 30s (Fig. 21.7b, c). Thomson first located Mijili's group near Lake McKay that lies on the Western Australian/ Northern Territory border, although her country was situated around Mount Webb in the southern part of the eastern Gibson Desert, southwest of Lake Mackay. These people came from the heart of the continent and a place that at time is so harsh it is unbelievable that anyone could survive there. It quite naturally gives a feeling that if you can survive there, you must possess some very special skills that enable you to do it. One of those is being able to track. But it is not just track; it is the almost microscopic nuances of a track - its shape, size, impression depth, surrounding soil removal and in what direction it's going, as well as other inflections that all together identify what made it, how long ago, its size and age, sex, direction of travel and how far away it might be. And it's not just tracks per se; it is marks on the ground around it or otherwise associated with it. It's also their width, length and circularity, whether 
they are repeated and at what frequency they repeat. It all sounds very scientific, but the skilled hunter can calculate it all in a split second. Too slow or unsure and the hunter loses food: that cannot be repeated too often!

All this would go into a Pintubi assessment of a track or mark, and that is what survival means. It is a shame, but those with such gifts are the old or elderly because you gather such skills with age and experience. But age and mortality in many situations where Aboriginal people are concerned do not necessarily correlate as they might in non-Aboriginal society. Aboriginal mortality often arrives at an unexpected and early age and with the death of an Elder culture disappears, particularly if the young are not interested in learning about it. The same occurs with languages, and of the 250 languages that once were spread across the continent, only about 50 have some speakers left. Therefore, the art of tracking, which is culture as well as a deeply incisive skill, is disappearing fast with the death of Elders. I can attest to this with the fact that the three humble and proud Elders that helped us are no longer with us.

What was humbling to me was that these particular Elders, with such special skills and nothing really to gain, agreed to come down and help us interpret our site. I believed that travel was going to be the real difficulty because many Aboriginal people, particularly tribal Elders like these, do not like to leave their country, at least not for long. When they first arrived, and before we had visited the site, their immediate observation was that the local Aboriginal people of the Willandra were the same as themselves; they were desert people. All indigenous people got on very well, and the local people were so glad to see these old people had come and visited them in their country. When the trackers came for a second visit, they brought a traditional digging stick for the local indigenous women as a gift for being in their country again and as a bond between them.

Old Paddy was one of the first to walk onto the site itself, and he was visibly amazed by what he saw. His demeanour then is not often seen with these often shy and reticent people from the desert. It was obvious that the trackers did not want to offend anybody or make the wrong move and were deeply aware that they were in someone else's country. Paddy's amazement manifested itself in his face but also his voice. He began to speak in whispers. He spoke his own language and could have spoken in any of the other five traditional languages that were known to him. It was obvious that English was not his favourite language and he did not speak it well. English does not describe his country, and so it didn't matter that he could not speak it well. It is after all a foreign language and not one that is from or describes his country the way it should be in a proper and respectful way. The principle is: if you don't know your language, you don't know your culture or how to understand and know your country.

As he walked across the white surface and spotted the first of the prints, his whispering was closely monitored by Peter Bartlett Japaljari who knew the Pintubi language very well. Peter told me later that Paddy had said this was a very ancient place, a Dreaming Place, a special place made by ancestral people. For Paddy that meant the people that these prints were ancestral beings who, for him, probably made many things in the dreamtime which has no date: it is deep in the past, continues to 
Fig. 21.8 (a) A hole in the clay surface made by the head of a spear while rested; (b) a doodle made by a child's finger in the mud

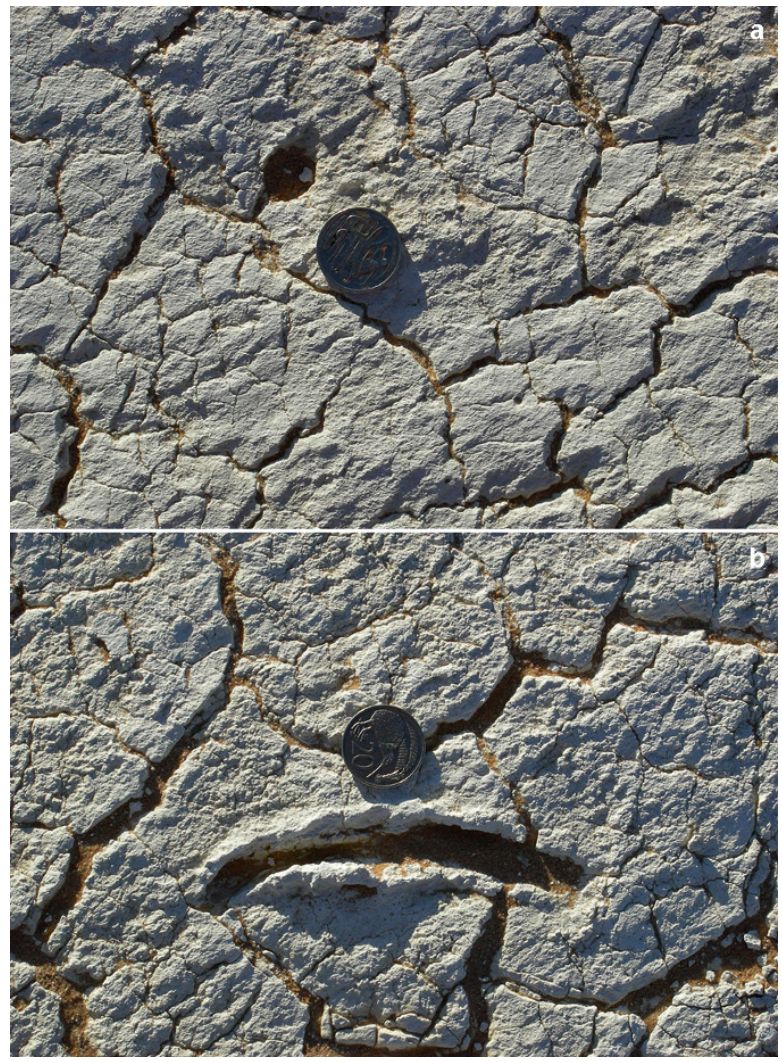

the present and goes on into the future. Paddy knew nothing of the age of the site. His whispers were the respect he had for the place and the fact that he believed he was in the presence of ancestral people who had long gone but whose spirits were still there. The only way I can describe it is like we do when we hush our voices when entering a church or cathedral even if we have no religious faith; it is automatic through experience and culture. Paddy almost glided across the surface in his stockinged feet, as was standard for walking on the site. His head under his large, grey bush hat moving very slowly from side to side as he peered through his glasses (Fig. 21.7d). He did not say much, but by that time, Johnny and Mijili were also walking slowly on the site. They were all quiet but looking. It was a special moment for all that were there. Peter told me that whatever could be learned from the surface, they would be able to tell us about it.

Mysterious marks were interpreted for us such as a group of lines of various widths had been made across the surface. The trackers told us this was where someone had dragged sticks or a branch across it possibly to build a fire somewhere. Another long mark we were told was where a spear had been thrown and ricocheted off the surface. There were small round holes in some places, and those were made by someone standing or resting their spear on its blunt end to keep the point sharp: "To keep the point sharp" (Fig. 21.8a). That seems logical, but Johnny wanted to 
Fig. 21.9 The track of a one-legged man with a missing left leg. The track crosses drag marks made by branches being dragged across the site

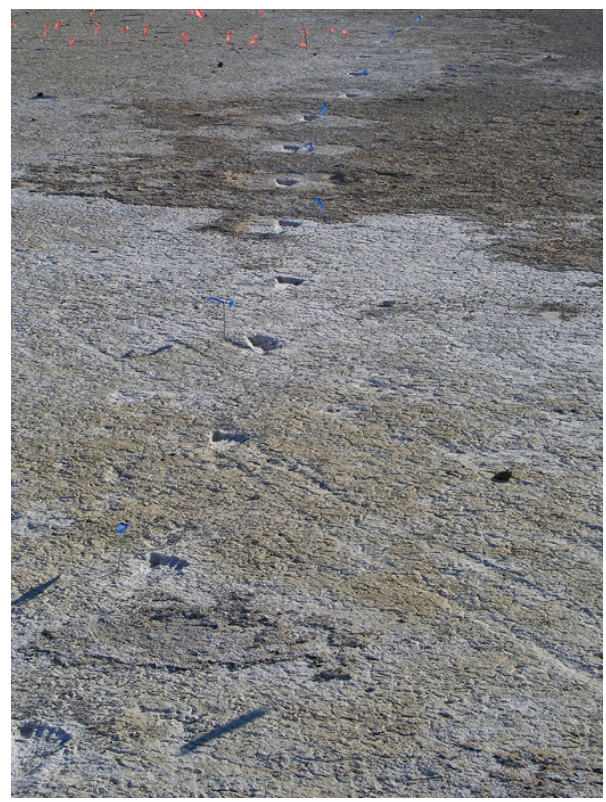

make it clear that you don't put a spear in the ground point first because you will blunt it and it will not be useful for hunting. Another feature was a shallow semicircle in the mud that the trackers interpreted as probably a child making a finger mark in the mud, in other words a Late Pleistocene doodle (Fig. 21.8b).

Probably the most baffling thing found on the site was a set of tracks that lacked a left footprint (Fig. 21.9). We looked in vain for any sign of a left foot and began to make up tales to explain what we were seeing. One idea was that this was a very shallow pond, which we were sure it was, but thought perhaps the track was of a man kneeling with his left leg inside a shallow dugout canoe while pushing the canoe along with his right. But footprints under water would have been unclear and largely mush, and the ones we had were very clear with details of the toes and other parts of the foot. So, we had put that on hold till the Pintubi trackers came. They knew immediately what the situation was. It was, indeed, a man without a left foot or leg. However, the stump of the leg with missing foot would have shown up as the opposite track, but that was not the case, so it was probably a large part or the whole of the leg was missing, most probably below the knee. Why? The trackers were not surprised by this discovery because they had known a man that had had his right leg amputated below the knee after it had been speared. The wound turned infectious and had rotted off. The man had then used the aid of a support pole to get about. When I first heard this, I thought of the support pole that would be needed to support the man as he hopped. It would also have left a tell-tale mark behind along one side of the foot track. We looked for such a track, but there was no sign of it. Then, was he hopping without a support pole? That would seem impossible 
Fig. 21.10 Site surface showing round imprints, possibly from the use of a support pole

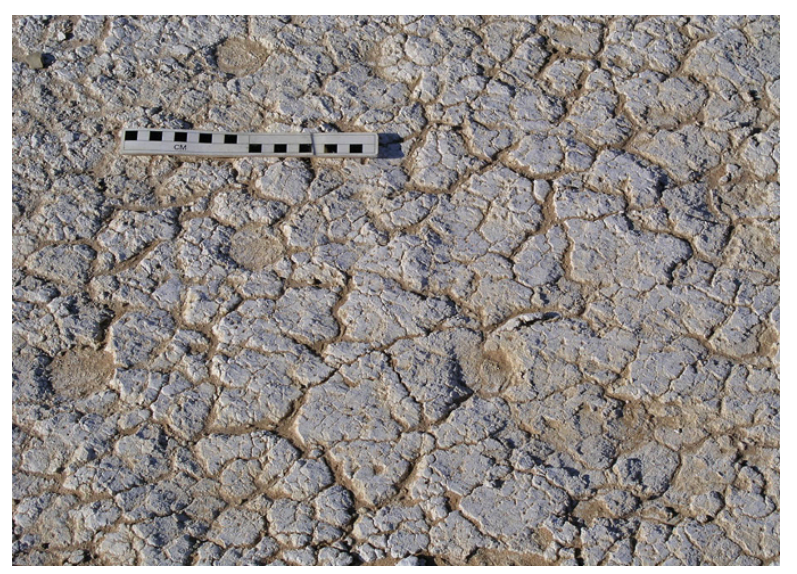

because the spacing between footprints looked too big to accommodate a hopping man. Once again, the trackers surprised us by telling us further details of the man known unsurprisingly as one leg. Peter Bartlett Japaljari had also known the man when he was very old. He was known as a great Elder, and many men had feared him in his younger days because of his strength and powers of sorcery. The trackers then told me of something that I would not have believed if they had told it to me. They said that the one-legged man could get up speed using the support pole and then at a certain point, he would drop it and continue hoping on one leg. This story seemed to exceed all bounds of human adaptation, but I was reassured it was true. That would certainly explain what we were seeing with this right-foot-only trackway. I mentioned before the trackers visited again and brought a gift for the local women. They also brought me one. They had made a support pole like the one-legged man's, made of mulga and with the pointed end fire-hardened. Then it dawned on us that the round marks we had seen in some parts of the site were probably made by a support pole (Fig. 21.10). If they were made in that way, they appeared on other layers below the top surface indicating repeat visits by the one-legged man and his group. That possibly tied down the span of the site to a few seasons or perhaps the lifetime of the one-legged man.

The detail that the trackers were able to provide us with was information that we could not have obtained in any textbook and even a lifetime in archaeology. What was revealing to us was that it was turning a basically flat archaeological site without the normal artefacts into an ancient activity area with living inhabitants with personalities and personal difficulties.

They were there for 5 days and then began to miss their country, so they set off for home. They did return bringing gifts, but that time it was to make a film of them on site. I have never seen the film that was made by an Aboriginal film organisation, and no one has ever mentioned it to me. I should seek it out as an archive, but I feel I saw the best film when the trackers first arrived and when they entered the site. I spoke to them and watched them. I sat with them as they sat round a campfire cooking a kangaroo that had been caught for them by a local parks and wildlife ranger. And I 
Fig. 21.11 Paddy Japananga teaching local boys how to use a spear thrower (woomera)

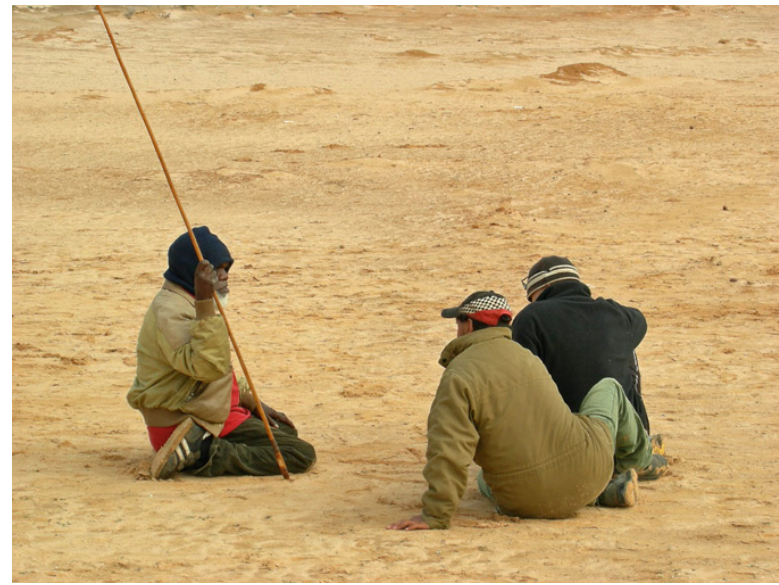

was in their presence in a natural way without pressure, not as a contrived scene in front of a camera. They also shared their time with the local Aboriginal people exchanging stories and laughing. One time I saw Paddy teaching some young men how to properly use a spear thrower and throw a spear (Fig. 21.11). That was also a bonus for the local people to mix with these special people from the distant desert country and make friends with them.

Those people had lived lives that represented how humans had survived in the past, whether 20,50 or 100 thousand years ago. They were people of today but had the skills of people that lived over thousands of years as part of the environment. They had skills that almost nobody on earth has today, and they generously shared them with us in order to help. During the work, I became close to Paddy Japananga during the work although I respected all of them greatly. I also had the great honour of being given the skin name Japananga by them so that I could join them and be involved with them in their universe in a way they could understand. From that they knew who I was and how I fitted into their world. They did not meet my family, but knowing that I was Japananga meant to them that my wife was a Naparulla woman, my son was a Japangarti man, his wife was a Nampinjimpa, their daughter will be Nangala and son Jangala, my daughter was a Napangarti and her husband was a Jampinjimpa, all that from knowing who I am. No writing and no records, it is a cultural system carried in the head. It makes you part of their system and weaves you into the fabric of the environment because all those names, and there are eight others, have obligations dictated by their skin name. By being a part of the skin section system, you know how you should behave, who you can and cannot talk to, who you can and cannot marry and who your offspring must marry and who your skin relatives are who are spread across a vast desert. It ties you to country, and you know where your place is in that country. One of those obligations is to look after your country and to treat it, and the life in it, properly and with respect; otherwise the ancestral spirits will take it from you. This is just a part of the very rich tapestry of 
knowledge and a closeness to the earth we have lost. Looking at ancient fossil footprints is looking at an echo of that loss.

Acknowledgements Dedicated to the memory and culture of Mijili Napananga, Paddy Japananga and Johnny Napurula. With many thanks to Peter Bartlett Japaljari and Cindy Nakamarra.

\section{References}

Thomson, D. (1975). Bindibu country. London: Thomas Nelson Press.

Webb, S. G. (2007). Further research of the Willandra Lakes fossil footprint site, southeastern Australia. Journal of Human Evolution, 52, 711-715.

Webb, S., Cupper, M. L., \& Robins, R. (2006). Pleistocene human footprints from Willandra Lakes, southeastern Australia. Journal of Human Evolution, 50, 405-413.

Open Access This chapter is licensed under the terms of the Creative Commons Attribution 4.0 International License (http://creativecommons.org/licenses/by/4.0/), which permits use, sharing, adaptation, distribution and reproduction in any medium or format, as long as you give appropriate credit to the original author(s) and the source, provide a link to the Creative Commons license and indicate if changes were made.

The images or other third party material in this chapter are included in the chapter's Creative Commons license, unless indicated otherwise in a credit line to the material. If material is not included in the chapter's Creative Commons license and your intended use is not permitted by statutory regulation or exceeds the permitted use, you will need to obtain permission directly from the copyright holder. 